\title{
Pengaplikasian Metode Activity Based Costing Pada Perhitungan Unit Cost Di Pelayanan Kesehatan Gigi Dan Mulut
}

Rika Irma Yanti ${ }^{1}$, Febrian¹, Desy Purnama Sari ${ }^{1}$

Korespondensi : Febrian; febrian@dent.unand.ac.id; Telp: 08116600655

\begin{abstract}
Dental clinic is one type of privateowned service enterprise providing dental and oral health services. In the current global era, dental clinics must be able to compete with other dental health facilities. Dental clinics are required to manage effectively clinical management, especially in financial accounting. Unit cost calculation using Activity Based Costing $(A B C)$ method is a modern calculation. It has been implemented in several health facilities. The basic concept of $A B C$ is a product derived from activities that will consume costs. The purpose of this paper is to provide an overview of the application of unit cost calculations with $A B C$ in dental clinics. So it can formulated four steps of unit cost calculation with $A B C$ as follows: preparation of data collection, data collection, $A B C$ calculation of the first stage, $A B C$ calculation of the second stage. The results of the calculation of unit cost with $A B C$ are clinical financial accounting data which are used as a consideration in making desicion of the clinical strategy.
\end{abstract}

Keywords: activity based costing; dental clinic; unit cost.

Affiliasi penulis : ${ }^{1}$ Fakultas Kedokteran Gigi, Universitas Andalas.

\section{PENDAHULUAN}

Klinik gigi adalah salah satu jenis perusahaan jasa swasta dalam upaya meningkatkan derajat kesehatan gigi dan mulut. Klinik gigi merupakan fasilitas kesehatan sosio-bisnis dimana tidak dipandang semata-mata untuk pengobatan melainkan profit juga diperhitungkan ${ }^{1}$. Perkembangan dunia kedokteran gigi telah mengalami peningkatan seiring dengan berkembangnya tingkat pendidikan serta upaya pemerintah dalam pembiayaan kesehatan gigi dan mulut. Hal ini mengakibatkan jumlah kunjungan pada pelayanan kesehatan gigi meningkat ${ }^{12}$. Peningkatan kunjungan tersebut berdampak pada bertambahnya jumlah fasilitas kesehatan gigi milik pemerintah maupun swasta baik klinik maupun rumah sakit gigi dan mulut ${ }^{3}$.Fasilitas pelayanan kesehatan gigi berada dalam suatu kompetisi yang tinggi baik dalam menarik maupun mempertahankan pasien sebagai konsumen utama ${ }^{1}$. Manajemen keuangan diperlukan untuk mengelola sumber daya yang dimiliki secara ekonomis, efektif dan efisien. Pengelolaan ini bertujuan untuk menghasilkan produk jasa yang memiliki struktur harga kompetitif. Hal tersebut dapat dilakukan dengan memahami pengendalian penyebab mendasar terjadinya suatu biaya ${ }^{4}$.

Unit cost adalah salah satu teori akuntansi biaya yang mana merupakan hasil perhitungan dari pembagian total biaya dengan jumlah unit terkait ${ }^{5}$. Perhitungan unit cost diperlukan untuk mengetahui besaran biaya yang benar-benar dibutuhkan untuk menghasilkan suatu produk baik berupa barang/jasa ${ }^{6}$. Informasi biaya yang dihasilkan mempunyai fungsi sentral antara lain digunakan untuk planning, budgeting, controlling dan penilaian organisasi. Selain digunakan untuk acuan dalam menyusun strategi ke depan juga 
untuk meningkatkan kapasitas layanan kesehatan serta menentukan keakuratan informasi biaya sebagai dasar dalam penentuan harga ${ }^{7}$.

Perhitungan unit cost dapat dilakukan dengan metode tradisional dan metode Activity Based Costing. Perhitungan unit cost dengan metode tradisional memiliki kekurangan yaitu biaya unit penunjang hanya dialokasikan pada satu atau dua alokasi. Jika metode ini diaplikasikan pada perusahaan yang memiliki berbagai jenis produk sering menyebabkan distorsi biaya ${ }^{8}$. Distorsi terjadi karena adanya ketidak akuratan dalam pembebanan biaya yang menyebabkan kesalahan penentuan biaya ${ }^{9}$. Perhitungan biaya yang tidak tepat akan memberikan informasi biaya yang tidak tepat pula yaitu undercosting atau overcosting yang dapat mengakibatkan kesalahan pengambilan keputusan ${ }^{10}$.

Activity Based Costing (ABC) merupakan metode penentuan harga pokok berdasarkan aktivitas yang dirancang untuk mengatasi masalah distorsi pada metode tradisional. Metode ini mulai diperkenalkan pada perusahaan-perusahaan di tahun 1990-an dan telah memberikan peningkatan bagi perusahaan tersebut ${ }^{11}$.. $A B C$ adalah sistem akuntansi yang terfokus pada aktivitas-aktivitas yang dilakukan untuk menghasilkan produk/jasa. Metode ABC memiliki keunggulan dengan penelusuran spesifik mengenai informasi tentang aktivitas dan sumber daya yang dibutuhkan untuk menghasilkan suatu produk. Perhitungan tarif dengan metode $A B C$ lebih akurat serta memudahkan dalam pengontrolan atau penghapusan biaya jika diperlukan? Selain itu, metode $A B C$ memberikan data yang jelas seperti pada data ekonomi serta biaya sumber daya suatu organisasi ${ }^{12}$. ABC dapat meningkatkan ketelitian dalam perincian biaya dan ketepatan biaya yang lebih akurat ${ }^{13}$. Metode $A B C$ menggunakan lebih dari satu cost driver yang menyebabkan metode ini sangat rinci dalam pengelompokan biaya dibandingkan dengan metode tradisional ${ }^{14}$. Sehingga metode ini menjadikan perusahaan akan lebih kompetitif, serta mengetahui kelemahan dan kekuatan dari perusahaan secara efisien ${ }^{15}$.

Pentingnya informasi biaya aktual dalam bidang kedokteran gigi bertujuan agar tercapainya pengelolaan yang efektif dan efisien. Maka dibutuhkan panduan perhitungan unit cost dengan ABC sebagai metode perhitungan akuntansi biaya. Tujuan penulisan ini untuk memberikan gambaran pengaplikasian perhitungan unit cost dengan metode $\mathrm{ABC}$ pada pelayanan kesehatan gigi dan mulut.

\section{Sub Judul}

\section{A. Teori Biaya}

Biaya (cost) adalah sumber daya yang dikorbankan atau dilepasakan untuk mencapai tujuan tertentu ${ }^{5}$. Biaya dalam kesehatan merupakan besaran dana yang harus disediakan untuk menyelenggarakan dan memanfaatkan berbagai upaya kesehatan yang diperlukan oleh perorangan, keluarga, kelompok dan masyarakat ${ }^{16}$. Klasifikasi biaya sangat banyak, beberapa diantaranya:

1. Klasifikasi biaya berdasarkan departemen terdiri dari biaya unit produksi dan biaya unit penunjang. Biaya unit produksi adalah biaya di suatu unit organisasi dimana proses produksi dilaksanakan secara langsung atas produk, baik dengan tangan maupun dengan mesin. Biaya unit penunjang adalah biaya di suatu unit organisasi secara tidak langsung terlibat dengan unit produksi. Departemen ini memberikan jasanya kepada unit-unit lain dalam suatu organisasi, kepada unit produksi atau kepada unit pendukung lainnya ${ }^{17}$. 
2. Klasifikasi biaya berdasarkan sesuatu yang dibiayai terdiri dari biaya langsung dan biaya tidak langsung. Biaya langsung adalah biaya yang disebabkan oleh adanya sesuatu yang dibiayai. Jika sesuatu yang dibiayai tersebut tidak ada maka biaya langsung tidak akan terjadi. Biaya tidak langsung adalah biaya yang terjadi tidak hanya disebabkan oleh sesuatu yang dibiayai. Biaya ini tidak dapat dihubungkan langsung dengan unit yang diproduksi ${ }^{18}$.

3. Klasifikasi biaya berdasarkan lama penggunaan terdiri dari biaya investasi, biaya operasional, dan biaya pemeliharaan. Biaya investasi adalah biaya yang dampak penggunaanya dapat berlangsung lama, biasanya untuk batas waktu penggunaanya lebih dari setahun. Biaya operasional adalah biaya yang diperlukan untuk menjalankan, memfungsikan, atau mengoperasi barang investasi untuk menghasilkan produk/jasa. Biaya pemeliharaan adalah biaya yang fungsinya untuk mempertahankan atau memperpanjang usia pemakaian barang investasi ${ }^{19}$.

4. Klasifikasi biaya berdasarkan aktivitas terdiri dari biaya tetap dan biaya variable. Biaya tetap adalah biaya yang tidak berubah secara total untuk waktu tertentu, meskipun perubahan besar dalam tingkat terkait total aktivitas atau volume. Biaya variabel adalah biaya yang jumlah totalnya akan berubah seiring dengan perubahan aktivitas atau volume produksi. Dari kedua jenis biaya tesebut diperoleh jenis biaya yang lain seperti biaya total dan biaya satuan/unit cost. Biaya total merupakan biaya keseluruhan meliputi jumlah dari biaya tetap dan biaya variabel ${ }^{20}$. Unit cost adalah hasil perhitungan dari pembagian total biaya dengan jumlah unit terkait ${ }^{5}$.

\section{B. Perhitungan unit cost dengan metode $A B C$}

Activity Based Costing ( $\mathrm{ABC}$ ) adalah suatu sistem penetapan biaya dengan mengidentifikasi aktivitas-aktivitas sebagai objek mendasar yang mempengaruhi biaya. ABC membantu dalam mengambil keputusan strategi, karena sistem $A B C$ akan mengidentifikasi aktivitas dari semua kegiatan, menghitung biaya aktivitas individu dan menetapkan biaya untuk objek biaya ${ }^{5}$. Istilah-istilah mendasar perhitungan ABC sebagai berikut:

\section{Aktivitas}

Klasifikasi level activity dalam perhitungan $\mathrm{ABC}$ terdiri dari unit-level activities (merupakan jenis aktivitas yang dikonsumsi oleh produk berdasarkan unit yang dihasilkan oleh aktivitas tersebut), batch-level activities (merupakan jenis aktivitas yang dikonsumsi oleh produk berdasarkan batch produk yang diproduksi), product sustaining activitiesa (merupakan jenis aktivitas yang dikonsumsi oleh produk jasa berdasarkan jenis produk yang dihasilkan oleh aktivitas tersebut), facility-sustaining activities (merupakan adalah aktivitas yang tidak dapat di hubungkan secara langsung dengan produk/jasa yang di hasilkan tetapi untuk mendukung organisasi secara keseluruhan) ${ }^{21}$. Klasifikasi aktivitas lainnya dapat dikelompokkan menjadi dua dalam menghasilkan suatu produk pada suatu organisasi terdiri dari aktivitas primer (merupakan kegiatan produksi hasil langsung dalam output suatu organisasi) dan aktivitas sekunder (merupakan aktivitas pendukung, merupakan aktivitas yang mendukung kegiatan primer dan biasanya bersifat administratif) ${ }^{22}$. 
2. Cost pool

Cost pool adalah kelompok biaya dari level activity dan cost drive yang sama ${ }^{23}$. Cost pool digambarkan pada suatu perusahaan mulai dari yang luas seperti semua biaya pabrik hingga yang sempit seperti biaya mengoperasikan mesin pemotong logam. Kemudian dilakukan pengelompokan dari semua elemen biaya yang berkaitan dengan suatu aktivitas sehingga diperoleh cost poof .

\section{Cost driver}

Cost driver adalah sebuah variabel, seperti level aktivitas atau volume yang mempengaruhi secara kasual biaya selama rentan waktu tertentu. Cost driver ada dua jenis yaitu resource driver dan activity driver. Resource driver merupakan faktor pengukuran sumber daya yang dikonsumsi oleh suatu aktivitas. Activity driver merupakan karakteristik yang menyebabkan terjadinya aktivitas di unit penunjang yang akan terbebankan pada aktivitas unit produksi ${ }^{24}$.

\section{Pembebanan biaya}

ABC memiliki konsep pembebanan biaya yang terdiri dari pembebanan biaya tahap I dan pembebanan biaya tahap II. Pembebanan biaya tahap I merupakan biaya tidak langsung yang akan dibebankan terhadap aktivitas-aktivitas bukan pada unit organisasi. Pembebanan biaya tahap II merupakan biaya tidak langsung setiap aktivitas akan dibebankan ke masing-masing produk untuk menentukan harga pokok tiap produk-produk tersebut. Langkah yang digunakan dengan menghitung tarif pada pembebanan tahap pertama dan mengukur berapa jumlah konsumsi masing-masing produk. Digambarkan dengan persamaan sebagai berikut ${ }^{25}$

Biaya tidak langsung yang dibebankan $=$ Tarif kelompok $\times$ jumlah konsumsi tiap produk

\section{PEMBAHASAN}

Perhitungan $A B C$ yang dimulai dengan membuat pedoman wawancara ${ }^{26} 27$. Menurut penelitian yang dilakukan sebelumnya pertanyaan yang digunakan dalam wawancara antara lain terkait dengan: (a) Gambaran umum rumah sakit; (b) Jumlah pasien rumah sakit, jumlah hari pasien, dan fasilitas yang digunakan; (c) Jenis-jenis layanan yang ada di rumah sakit; (d) Prosedur pelayanan rumah sakit; (e) Aktivitas yang dilakukan rumah sakit untuk memberikan layanan kepada pasien; (f) Fasilitas yang ada untuk setiap layanan rumah sakit; (g) Biaya yang dibebankan untuk setiap layanan yang ada di rumah sakit ${ }^{11}$. Selain menggunakan pedoman wawancara, form pengisian data digunakan sebagai instrument yang dapat mempermudah proses pengumpulan data di lapangan ${ }^{28} 29$. Setelah melakukan survey di lapangan maka akan diperoleh data primer dan sekunder. Data primer diperoleh dari observasi dan wawancara terhadap pihak yang bersangkutan. Data sekunder diperoleh dari sumber-sumber tertulis berupa data keuangan, dan data lain terkait masalah yang dibahas ${ }^{30}$.

Setelah data-data terkumpul selanjutnya dilakukan perhitungan $A B C$ tahap pertama berupa penelusuran alur klinis/clinical pathway di suatu organisasi. Dimulai dari pasien datang, mendaftar ke front office, menunggu antrian, pemeriksaan umum dan pelayanan, diagnosis, tindakan, pengambilan obat di apotek sampai pasien pulang ${ }^{31}$. Setelah pathway setiap tindakan diketahui langkah selanjutnya menentukan klasifikasi aktivitas-aktivitas di setiap pelayanan. Contoh klasifikasi aktivitas-aktivitas yang dilakukan dalam 
pelayanan rawat inap di suatu rumah sakit sebagai berikut aktivitas pelayanan cleaning service merupakan bacth level activity, aktivitas pelayanan perawatan pasien merupakan unit level activity, pelayanan apotek dan administrasi merupakan bacth level activity, aktivitas pelayanan pemeliharaan bangunan merupakan fasility sustaining level activity. Setiap aktivitas-aktivitas untuk memperoleh suatu pelayanan akan diklasifikasikan pada level aktivitas tersebut ${ }^{32}$. Selanjutnya Setelah mengklasifikasikan aktivitas berdasarkan pathway maka diklasifikasikan lagi jenis aktivitas pada unit produksi yang terdiri dari aktivitas primer dan aktivitas sekunder. Salah satu contoh klasifikasi aktivitas suatu penelitian di unit kardiologi dimana aktivitas primer berupa memberikan treatment ke pasien, merespon pertanyaan pasien, memonitoring pasien. Aktivitas sekunder berupa aktivitas yang dilakukan oleh perawat seperti membuat skejul, membuat koordinsi dan sebagainya ${ }^{33}$.

Analisis biaya dilakukan setelah aktivitas-aktivitas ditelusuri sehingga dapat menentukan biaya-biaya yang dikonsumsi aktivitas tersebut. Klasifikasi biaya berdasarkan departemen terdiri dari biaya unit produksi, terdapat dua jenis biaya yaitu biaya langsung dan tidak langsung unit produksi ${ }^{26}$. Biaya langsung terdiri dari penjumlahan biaya bahan habis pakai atau BHP medis, biaya pegawai pertindakan, dan biaya alat medis yang digunakan ${ }^{34}$. Biaya tidak langsung unit produksi berupa BHP non medis, alat non medis, gaji pegawai non medis, biaya umum (listrik, air, telepon, internet) dan lain sebagainya ${ }^{26}$. Biaya unit penunjang merupakan biaya diluar unit produksi yang digunakan secara tidak langsung demi kelancaran proses produksi/pelayanan. Biaya ini seperti biaya tenaga kerja non medis, biaya alat non medis, BHP non medis/kebutuhan kantor, biaya umum (listrik, telpon, air, dll) ${ }^{20}$.

Setelah aktivitas diidentifikasi maka selanjutnya akan diidentifikasi cost driver tiap aktivitas. Cost driver merupakan data pendukung yang diambil dalam pencarian informasi dan memiliki faktor-faktor penyebab yang menjelaskan pada biaya unit penunjang ${ }^{20}$. Penelitian yang dilakukan pada produk pelayanan rawat inap di suatu rumah sakit memiliki cost driver disetiap aktivitasnya. Contoh cost driver seperti pada aktivitas pelayanan administrasi umum memiliki cost driver berupa jumlah pasien rawat inap, aktivitas pelayanan perawatan pasien memiliki cost driver jumlah hari rawat. Keempat, Aktivitas pelayanan pembersihan memiliki cost driver berupa luas ruangan ${ }^{32}$. Tujuan mengetahui cost driver setiap aktivitas untuk dapat menentukan nilai kelompok aktivitas dan tarif ${ }^{35}$. Selanjutnya menentukan cost pool pada pelayanan tergantung pada level aktivitas dan cost drive ${ }^{36}$. Mengumpulkan biaya sumber daya dalam suatu kelompok yang disebut kelompok biaya atau cost pool. Cost pool merupakan pengelompokan dari beberapa aktivitas yang mengkonsumsi biaya dengan cost driver yang sama. Contoh cost pool pada klinik gigi seperti cost pool I berupa pelayanan konsultasi, cost pool II berupa pelayanan penambalan GIC, cost pool III berupa pelayanan pencabutan gigi dan lain sebagainya. maka akan di kelompokkan untuk memudahkan dalam perhitungan tarif/cost pool rate nantinya.

Perhitungan $A B C$ tahap kedua terdiri dari menghitung biaya unit penunjang, biaya unit produksi, pembebanan biaya sera perhitungan unit cost dengan metode ABC. Pada penelitian yang dilakukan di poli mata, yang termasuk unit penunjang berupa pelayanan administrasi terpadu, pelayanan rekam medik, pelayanan laundry, pelayanan keamanan dan sebagainya ${ }^{26}$. Biaya-biaya yang ada pada unit penunjang seperti depresiasi gedung, depresiasi alat medis, depresiasi kendaraan, BHP non medis, gaji pegawai, biaya umum (biaya listrik dan telepon) serta biaya pemeliharaan gedung dan fasilitas lainnya akan di totalkan²0. 
Kemudian biaya unit penunjang seperti biaya investasi berupa gedung, kendaraan dan alat merupakan perhitungan yang disetahunkan atau biasa disebut dengan Annualized Investment Cost (AIC) ${ }^{37}$.

Selanjutnya menghitung biaya unit produksi terdiri dari perhitungan biaya tidak langsung dan biaya langsung unit produksi. Perhitungan Biaya tidak langsung pada unit produksi terdiri dari AIC gedung unit produksi dan alat non medis, BHP non medis, biaya gaji pegawai non medis, biaya umum (telpon, listrik, air, internet) dan biaya lainnya yang terkait. Kemudian perhitungan biaya langsung unit produksi terdiri dari biaya BHP medis, gaji pegawai medis dan biaya investasi alat medis. Menghitung BHP medis di unit produksi diperoleh dari hasil membagi berat/besar pemakaian $(\mathrm{g}$ ) dengan total berat pada satu botol/kemasan dikali harga beli satu botol/kemasan, Sehingga akan didapatkan harga bahan medis yang digunakan untuk satu pasien. Menghitung gaji pegawai medis diperoleh dari mencari gaji pegawai permenit dengan cara mentotalkan gaji setiap dokter gigi dan perawat gigi selama setahun dibagi waktu pelayanan klinik selama setahun ${ }^{34}$. Kemudian menghitung gaji pertindakan dengan cara gaji per menit dikali dengan cost driver gaji berupa waktu pelayanan maka akan didapatkan nilai gaji pertindakan ${ }^{34}$. Menghitung biaya investasi alat medis, langkah pertama yang dilakukan adalah mencari nilai biaya depresiasi alat dengan menggunakan rumus AIC. Setelah itu menentukan biaya depresiasi alat permenit diperoleh dari nilai perbandingan biaya depresiasi alat dengan waktu pelayanan pertahun. Kemudian mencari biaya depresiasi alat pertindakan diperoleh dari hasil perkalian biaya depresiasi alat per menit dengan cost driver alat medis (waktu pelayanan).

Tahap selanjurnya pembebanan biaya terdiri dari pembebanan biaya tahap I dan pembebanan biaya tahap II. Pembebanan biaya tahap I merupakan pembebanan biaya tidak langsung pada unit penunjang ke unit produksi ${ }^{26}$. Langkah pertama yang dilakukan adalah menghitung tarif kelompok aktivitas (cost pool rate) didapatkan dengan cara perbandingan total biaya pelayanan unit penunjang dengan cost driver yang digunakan pada setiap pelayanan unit penunjang tersebut ${ }^{3}$. Setelah didapatkan cost pool rate per aktivitas unit penunjang maka perhitungan pembebanan biaya dapat dilakukan dengan menggunakan nilai cost pool rate tadi. Nilai pembebanan biaya tahap I didapatkan dengan mengkalikan nilai cost pool rate dengan cost driver unit produksi tersebut ${ }^{26}$. Pembebanan biaya tahap II merupakan pembebanan biaya tidak langsung pada unit penunjang dan biaya tidak langsung pada unit produksi dibebankan ke setiap pelayanan unit produksi ${ }^{26}$. Pembebanan pada tahap ini dilakukan dengan membedakan antara aktivitas primer dan aktivitas sekunder. Cost driver pembebanan biaya yang digunakan adalah waktu peraktivitas dalam pelayanan dan jumlah pasien dalam pelayanan yang sudah ditentukan sebelumnya. Dimana cost driver berupa hasil perkalian dari jumlah waktu yang dibutuhkan dengan jumlah pasien pelayanan ${ }^{37}$. Selanjutnya seluruh biaya tidak langsung baik sekunder maupun primer di distribusikan berdasarkan jumlah cost driver per aktivitas masing-masing. Jumlah cost driver yaitu jumlah keseluruhan cost driver primer dan sekunder di setiap aktivitas sedangkan jumlah cost driver primer yaitu jumlah keseluruhan cost driver aktivitas primer ${ }^{20}$.

Perhitungan biaya produk tidak langsung pada penggabungan aktivitas sekunder merupakan hasil perhitungan pembebanan unit penunjang di masing-masing unit produksi. Maka biaya tidak langsung diambil dari jumlah yang telah dihitung pada pembebanan unit penunjang. Langkah berikutnya menentukan biaya tidak langsung pada aktivitas sekunder unit produksi dengan cara membagi cost drive peraktivitas 
Fakultas Kedokteran Gigi Universitas Andalas

Jalan Perintis Kemerdekaan No. 77 Padang, Sumatera Barat

Web: adj.fkg.unand.ac.id Email: adj@dent.unand.ac.id

dengan total seluruh cost drive. Kemudian hasil pembagian tersebut dikalikan dengan total biaya tidak langsung unit produksi yang diperoleh sebelumnya ${ }^{26}$. Setelah diketahui biaya tidak langsung setiap aktivitas di unit produksi langkah selanjutnya melakukan pembebanan biaya. Pembebanan biaya dari aktivitas sekunder ke aktivitas primer dengan cara membagi cost drive tiap aktivitas primer dengan total seluruh cost drive aktivias primer kemudian hasil pembagian tersebut dikalikan dengan biaya tidak langsung setiap aktivitas sekunder yang dibebankan. Langkah selanjutnya adalah menentukan alokasi sekunder ke primer dengan mengelompokkan aktivitas sekunder yang digunakan dalam aktivitas primer kemudian melakukan pembebanan biaya tidak langsung pada setiap aktivitas primer ${ }^{26} 37$. Nilai pembebanan biaya dari aktivitas sekunder dan unit penunjang yang dibebankan ke aktivitas primer kemudian ditotalkan sehingga diperoleh nilai total biaya tidak langsung per aktivitas primer. Langkah selanjutnya menentukan rate cost peraktivitas primer dengan cara membagi total biaya tidak langsung yang sudah dibebankan dengan jumlah pasien pelayanan tersebut 2637 . Total rate cost pada pembebanan biaya merupakan nilai biaya tidak langsung yang digunakan untuk perhitungan unit cost ${ }^{26}$. Langkah terakhir merupakan perhitungan unit cost diperoleh dari hasil penjumlahan antara seluruh biaya tidak langsung dan biaya langsung pada setiap produk pelayanan ${ }^{26} 34$. Salah satu contoh perhitungan unit cost dilihat pada tabel dibawah ini:

Tabel 1. Perhitungan Unit Cost di Klinik Spesialis Bedah Saraf

\begin{tabular}{clccc}
\hline No & \multicolumn{1}{c}{ Produk Pelayanan } & $\begin{array}{c}\text { Biaya } \\
\text { Langsung (Rp) }\end{array}$ & $\begin{array}{c}\text { Biaya Tidak } \\
\text { Langsung (Rp) }\end{array}$ & $\begin{array}{c}\text { Unit Cost } \\
\text { (Rp) }\end{array}$ \\
\hline 1 & Konsultasi dokter & 312.221 & 211.805 & 296.168 \\
2 & $\begin{array}{l}\text { Injeksi Keloid/Injeksi akupuntur } \\
\text { besar }(>5 \mathrm{~cm})\end{array}$ & 250.786 & 350.669 & 662.890 \\
3 & $\begin{array}{l}\text { Injeksi Keloid/Injeksi akupuntur kecil } \\
\text { ( } \leq 5 \mathrm{~cm})\end{array}$ & 103.698 & 350.669 & 601.455 \\
4 & $\begin{array}{l}\text { Rawat luka tanpa angkat jahitan } \\
\text { kecil }(1-5 \text { jahitan) }\end{array}$ & 124.960 & 131.148 & 234.846 \\
\hline
\end{tabular}

Sumber: Rahmaniar \& Rochmah (2017)

\section{SIMPULAN}

Perhitungan unit cost dengan activity based costing $(\mathrm{ABC})$ adalah perhitungan paling modern yang telah diterapkan dibeberapa perusahaan serta fasilitas kesehatan. Konsep dasar ABC terfokus pada setiap aktivitas yang mengkonsumsi biaya untuk menghasilkan produk/jasa. $A B C$ melakukan penelusuran spesifik mengenai informasi tentang aktivitas dan sumber daya yang dibutuhkan untuk menghasilkan suatu produk. Perhitungan $A B C$ memiliki lebih dari satu cost driver yang menyebabkan perhitungan ini lebih efektif dibandingkan perhitungan secara tradisional. Sehingga dari perhitungan unit cost menggunakan $A B C$ 
Fakultas Kedokteran Gigi Universitas Andalas

Jalan Perintis Kemerdekaan No. 77 Padang, Sumatera Barat

Web: adj.fkg.unand.ac.id Email: adj@dent.unand.ac.id

didapatkan data yang jelas mengenai akuntansi keuangan klinik yang digunakan sebagai pertimbangan dalam menyusun strategi kedepan.

Penghitungan $A B C$ di klinik gigi terdiri dari empat langkah yaitu langkah pertama persiapan pengumpulan data berupa persiapan pertanyaan wawancara dan form pengisian data. Langkah kedua pengumpulan diperoleh dari wawancara langsung dengan informan dibantu dengan form pengisian data yang telah dipersiapkan. Langkah ketiga perhitungan $\mathrm{ABC}$ tahap pertama berupa menentukan clinical pathway pada klinik, menentukan klasifikasi aktivitas, analisis biaya aktivitas, penentuan cost driver dan penentuan cost pool. Langkah keempat perhitungan $A B C$ tahap kedua berupa perhitungan biaya unit penunjang, perhitungan biaya langsung dan tidak langsung unit produksi, pembebanan biaya serta perhitungan unit cost.

\section{KEPUSTAKAAN}

1. Rahmilia Y. Pengaruh Reputasi Klinik Dokter Gigi Terhadap Rekomendasi dan Loyalitas Pasien. J Manaj dan Pemasar Jasa 2015, pp. 8.

2. Heningtyas $\mathrm{AH}$, Dewanto I. Dental Visir, Dental Diseases, and Dental Therapist Pattern in The Implementation of NHI at Private Clinics. J Indones Dent Assoc 2019, pp. 2.

3. Nailufar U. PENERAPAN ACTIVITY BASED COSTING SYSTEM DALAM MENENTUKAN HARGA POKOK JASA RAWAT INAP (Studi pada RSUD Ibnu Sina Kabupaten Gresik Tahun 2013). J Adm Bisnis S1 Univ Brawijaya, 2015; 24: 86031.

4. Wahyuni NT, Junaid H, Rasma. Analisa Unit Cost Pelayanan Rawat Inap Postpartum di Rumah Sakit Umum Dewi Sartika dengan Menggunakan Metode Activity Based Costing (ABC) Sydtem. jimkesmas 2017, pp. 2.

5. Charles T. Horngen, Srikant M. Datar MVR. cost Accounting, A Managerial Emphasis. 2012.

6. Damayanti T. Analisis Unit Cost Sectio Caesaria dengan Metode Activity Based Costing di Rumah Sakit Bhayangkara Yogyakarta. J Medicoeticolegal dan Manaj Rumah Sakit 1018196/jmmr2016 2017; 6: 16-23.

7. Mulyono I. Model Perhitungan Unit Cost Layanan Kesehatan Dengan Metode Biaya Konvensional Dan Abc (Studi Kasus Di Puskesmas "X" Kabupaten Lumajang). J Anal Akunt dan Perpajak, 2017, pp. 1. doi:10.25139/jaap.v1i1.98.

8. Martusa R. Peranan Metode Activity Based Costing Dalam Menentukan Cost of Goods Manufactured. Akurat J IIm Akunt 2010; 2: 27-40.

9. on R. Hansen MMM. No Managerial Accounting. 2005.

10. Hilfi L., et al., Perbedaan Perhitungan Unit Cost dengan Menggunakan metode Activity Based Costing (ABC) dan Metode Doubel Distribution (DD) Untuk Pasien TB Paru Kategori 2 di Instalasi Rawat Jalan Dan Rawat Inap Rumah Sakit Paru. J Sist Kesehat 2017; 1: 63-70.

11. Jayanti N, Mildawati T. Penerapan Activity Based Costing pada Tarif Jasa Rawat Inap Rumah Sakit (Studi pada Rumah Sakit Wiyung Sejahtera Surabaya). J Ilmu dan Ris Akunt 2014, pp. 3.

12. Cokins G. Activity Based Cost Management An Executive’s Guide. New York, 2001. 
13. Walandouw SK, Kaunang B. Penerapan Metode Activity Based Costing System Dalam Menentukan Besarnya Tarif Jasa Rawat Inap Pada Rumah Sakit Umum Bethesda Kota Tomohon. J Ris Ekon Manajemen, Bisnis dan Akunt 2015; 3: 1214-1221.

14. Puspitawati DI, Ratnawati T. Analisis Kinerja Kemandirian Keuangan Dan Aktivitas Layanan Rawat Inap Utama Pada Badan Layanan Umum Daerah Rumah Sakit Jiwa Menur Dengan Metode Activity Based Costing. J Ilmu Ekon Manaj Januari 2014; 10: 16-26.

15. Sabijono H, Panekenan I. Penerapan Metode Activity Based Costing Dalam Menentukan Besarnya Tarif Jasa Inap Pada Penginapan Vili Calaca Manado. J Ris Ekon Manajemen, Bisnis dan Akunt 2014; 2: 1417-1428.

16. Azwar A. Pengantar Administrasi Kesehatan. Binarupa Aksara: Jakarta, 1997.

17. Dunia FA, Abdullah W. Akuntansi Biaya. Salemba Empat: Jakarta, 2012.

18. Mulyadi. Sistem Akuntansi. Salemba Empat: Yogyakarta, 2014.

19. Ramadhani D, Merida, Hendrani A, Suheri. Akuntansi Biaya (Konsep dan Implementasi di Industri Manufaktur). CV.Markumi: Yogyakarta, 2020.

20. Hariyani DS. Akuntansi Manajement Teori dan Aplikasi. Pertama. Aditya Media Publishing: Yogyakarta, 2018.

21. Mulyadi. Ekonomi Sumber Daya Manusia dalam Presfektif Pembangunan. PT. Raja Grafindo Persada: Jakarta, 2003.

22. Waters $\mathrm{H}$, Abdallah $\mathrm{H}$, Santillán $\mathrm{D}$. Application of activity-based costing (ABC) for a peruvian NGO healthcare provider. Int $J$ Health Plann Manage 2001; 16: 3-18.

23. Febrian ., et al., Comparative Study of Unit Cost-analysis among Urban and Rural Dental Primary Health Services in Padang City, Indonesia. J Clin Diagnostic Res 2019; 13: $26-29$.

24. Horngren CT, Foster G, Datar SM, Rajan M, Ittner C, Baldwin AA. Cost Accounting: A Managerial Emphasis, 2010 doi:10.2308/iace.2010.25.4.789.

25. Bambang H. Akuntansi Manajemen Suatu Sudut Pandang. edisi pert. BPFE: Yogyakarta, 2002.

26. Sugiyarti AT, Sandra C, Administrasi B, Masyarakat FK, Jember U. Analisis Biaya Satuan (Unit Cost ) Dengan Metode Activity Based Costing ( $A B C$ ) ( Studi Kasus di Poli Mata RSD Balung Kabupaten Jember ) Unit Cost Analysis ( Unit Cost) With Activity Based Costing Method ( ABC ) ( Case Study In Eyes at RSD Balung Jember. Bagian AKK FKM Univ JEMBER 2013, pp. 1.

27. Ahmad Putri DR, Saifi M, Hidayat R. Penerapan Sistem ABC (Activity Based Costing System) Sebagai Alternatif Dasar Pembebanan Biaya Overhead Pabrik (Studi Kasus Pada PT. Wonojati Wijoyo Kediri Jawa Timur)". J Adm Bisnis S1 Univ Brawijaya 2016; 35: 18-27.

28. Aprinanda WT, Misnaniarti, Budi IS. METODE ACTIVITY BASED COSTING DALAM PENENTUAN TARIF RAWAT INAP DI RSUD KAYUAGUNG TAHUN 2012. J ILMU Kesehat Masy 2013.

29. Putri N, Handayani S. ANALISIS PERBANDINGAN METODE KONVENSIONAL DAN METODE ACTIVITY BASED COSTING ((ABC) UNTUK TARIF RAWAT INAP (Studi Kasus pada RSUD DR. Saiful Anwar (RSSA) Kota Malang). J Adm Bisnis S1 Univ Brawijaya 2017; 47: 16-24. 
Fakultas Kedokteran Gigi Universitas Andalas

Jalan Perintis Kemerdekaan No. 77 Padang, Sumatera Barat

Web: adj.fkg.unand.ac.id Email: adj@dent.unand.ac.id

30. Makal VS, Nangoi GB. APPLICATION OF ACTIVITY BASED COSTING AS THE BASIS FOR DETERMINATION OF TARIFF INPATIENT HOSPITAL IN PROF.DR.RD. KANDOU MANADO. $J$ EMBA 2015.

31. Sari IP, Arisandi D. Sistem Informasi Manajemen Klinik Gigi Berbasis Client Server (Studi Kasus Poliklinik Gigi RSJ Tampan, Pekanbaru. J Teknol dan Sist Inf Univrab 2017, pp. 2.

32. Zifi MP, Renaldo ZA, Salsabila R, Riau PC. PERBANDINGAN TARIF JASA RAWAT INAP MENGGUNAKAN METODE TRADITIONAL COSTING DAN Abstrak. 2020; 3: 129-140.

33. Mowen M, Hansen D. Introduction to Cost Accounting. South-Western: Cengage Learning. International Edition., 2011.

34. Rahmaniar D, Rochmah TN. Analisa Biaya Satuan Metode Activity Based Costing (ABC) dalam Evaluasi Tarif Pelayanan di Klinik Spesialis Bedah Saraf Rumah Sakit 'X' Surabaya. Jurnam Manaj Kesehat Yayasan RS Dr Soetomo 2017, pp.3.

35. Mursalin. Penerapan Metode Activity Based Costing(ABC)Dalam Penentuan Tarif Jasa Rawat InapDi Rumah Sakit Umum Daerah (RSUD) Hasanuddin Damrah Bengkulu Selatan. J Media Wahana Ekon 2019; 16.

36. Febrian F, Lukman S, Hardisman H, Suhairi S. Perhitungan Biaya Layanan Gigi di Klinik Pratama Menggunakan Metode. 2020, pp. 46-51.

37. Witcahyo E. Perhitungan Biaya Satuan Pada Tindakan Intensive Unit Care di Rumah Sakit X di Jember Melalui Metode Activity Based Costing (ABC). J Ekon Kesehat Indones 2019; 4: 32-42. 